\title{
VIABILITAS POLEN DAN AKUMULASI CADANGAN MAKANAN DALAM BIJI PADI AKIBAT CEKAMAN SUHU TINGGI
}

\author{
Risky Ridha ${ }^{\left.1^{*}\right)}$ \\ ${ }^{1)}$ Program Studi Agroteknologi, Fakultas Pertanian, Universitas Samudra, Kota Langsa. \\ *e-mail : riskyridha@unsam.ac.id
}

\begin{abstract}
Abstrak
Cekaman suhu tinggi merupakan salah satu cekaman lingkungan abiotik yang disebabkan oleh peningkatan suhu lingkungan akibat dari perubahan iklim. Budidaya di dataran rendah terdapat beberapa permasalahan yang dihadapi seperti adanya musim kering yang panjang atau rentannya terhadap cekaman suhu tinggi. Fase booting dan pembungaan pada tanaman padi adalah fase yang paling sensitif terhadap suhu tinggi. Suhu tinggi selama kedua fase ini dapat menyebabkan kehampaan total. Selama tahap ini, stress akibat panas sangat memungkinkan untuk terjadinya strerilitas bunga, menurunnya kesuburan dan kehilangan hasil. Hal ini terutama disebabkan oleh menurunnya aktifitas serta perkecambahan polen, terbatasnya pertumbuhan tabung polen, rendahnya daya dehiscence polen, rendahnya polen yang mencapai kepala putik dan penyerbukan yang tidak sempurna. Temperatur secara langsung juga berperan terhadap perkembangan biji seperti pengisian biji dan laju produksi bahan kering pada biji. Suhu tinggi selama periode pengisian biji menyebabkan penurunan yang signifikan terhadap ukuran biji dan kandungan amilosa. Stres suhu tinggi selama tahap pemasakan memicu pengisian yang tidak seragam dan gangguan dalam biosintesis penyimpanan, yang menyebabkan pembentukan kapur Akibatnya, biji berkapur dengan mudah retak selama pemrosesan biji, yang menurunkan persentase beras kepala sebagai akibat dari peningkatan jumlah biji yang patah.
\end{abstract}

Kata Kunci : Suhu tinggi, padi, viabilitas polen dan cadangan makanan.

\section{PENDAHULUAN}

Cekaman suhu tinggi merupakan salah satu cekaman lingkungan abiotik yang disebabkan oleh peningkatan suhu lingkungan akibat dari perubahan iklim. IPCC, (2013) telah melaporkan bahwa pada akhir abad ke-21 rata-rata suhu permukaan bumi akan meningkat antara 2-4 ${ }^{\circ} \mathrm{C}$. Berdasarkan data suhu tahun 2015, di Indonesia telah terjadi peningkatan suhu sebesar $0.65-1.43{ }^{\circ} \mathrm{C}$ (BMKG, 2015). Penurunan hasil pertanian dapat mencapai lebih dari $20 \%$ apabila suhu udara naik melebihi $4{ }^{0} \mathrm{C}$ di atas suhu optimum (Tschirley, 2007).
Budidaya di dataran rendah terdapat beberapa permasalahan yang dihadapi seperti adanya musim kering yang panjang atau rentannya terhadap cekaman suhu tinggi. Dalam peningkatan produksi padi salah satu permasalahan adalah terjadinya peningkatan gabah hampa dan penurunan kualitas gabah terutama apabila saat fase reproduktif dan pematangan terjadi pada musim kering atau suhu tinggi.

Fase booting dan pembungaan adalah fase yang paling sensitif terhadap suhu tinggi. Suhu tinggi selama kedua fase ini dapat menyebabkan kehampaan total (Shah et al., 2011). Selama tahap ini, 
stress akibat panas sangat memungkinkan untuk terjadinya strerilitas bunga, menurunnya kesuburan dan kehilangan hasil. Hal ini terutama disebabkan oleh menurunnya aktifitas serta perkecambahan polen, terbatasnya pertumbuhan tabung polen, rendahnya daya dehiscence polen, rendahnya polen yang mencapai kepala putik dan penyerbukan yang tidak sempurna (Matsui et al., 2001; Tan et al., 2006).

Berbagai penelitian menunjukkan bahwa temperatur harian yang melebihi $35{ }^{0} \mathrm{C}$ pada saat pembungaan menyebabkan sterilitas floret pada padi. Penyebab utama sterilitas yang disebabkan oleh rendahnya dehiscence antheca saat pembungaan (Matsui et al., 2000). Selanjutnya Matsui et al., (1997) menyatakan bahwa pada varietas padi tertentu dengan temperatur $30{ }^{0} \mathrm{C}$ pada saat pembungaan dapat menyebabkan terjadinya sterilitas. Sterilitas tersebut dapat menyebabkan peningkatan gabah hampa sehingga mengurangi hasil seperti yang diharapkan.

Terdapat perbedaan yang sangat jelas akan sensitifitas terhadap temperatur tinggi diantara berbagai kultivar tanaman padi (Morita, 2008). Kultivar/varietas yang toleran terhadap temperatur tinggi menunjukkan anter dehiscence dan kesuburan floret yang lebih tinggi daripada varietas yang resisten pada keadaan temperatur tinggi (Matsui et al., 2001). Varietas yang sensitif terhadap temperatur tinggi dapat menghasilkan abnormalitas dari embrio sac. Keabnormalan embrio sac ini juga dapat mendorong terjadinya abnormalitas pada proses pembuahan (Zeng et al., 2008).

Temperatur secara langsung juga berperan terhadap perkembangan biji seperti pengisian biji dan laju produksi bahan kering pada biji (Kobata and Uemuki, 2004). Temperatur tinggi dapat menghambat perkembangan biji pada padi (Zakaria et al., 2002). Suhu tinggi selama periode pengisian biji menyebabkan penurunan yang signifikan terhadap ukuran biji dan kandungan amilosa (Yamakawa dan Hakata, 2010; Yamakawa et al., 2007). Stres suhu tinggi selama tahap pemasakan memicu pengisian yang tidak seragam dan gangguan dalam biosintesis penyimpanan, yang menyebabkan pembentukan kapur (Sreenivasulu et al., 2015). Akibatnya, biji berkapur dengan mudah retak selama pemrosesan biji, yang menurunkan persentase beras kepala sebagai akibat dari peningkatan jumlah biji yang patah (Sreenivasulu et al., 2015).

\section{DAMPAK CEKAMAN SUHU TINGGI TERHADAP VIABILITAS POLEN DAN PEMBENTUKAN BIJI}

Cekaman suhu tinggi adalah suatu kondisi suhu yang dihadapi oleh tanaman yang menyebabkan kerusakan yang tidak dapat baik. Suhu menjadi cekaman bagi tanaman bergantung pada laju perubahan, intensitas maupun durasinya. Cekaman suhu tinggi sering didefinisikan ketika terjadinya kenaikan suhu di luar batas suhu optimum pertumbuhan tanaman selama jangka waktu yang cukup untuk menyebabkan terganggunya pertumbuhan dan perkembangan tanaman yang tidak dapat balik. Secara umum, peningkatan 10-15 ${ }^{0} \mathrm{C}$ di atas suhu optimum pertumbuhan dianggap sebagai cekaman suhu tinggi (heat shock, heat stress) (Wahid et al., 2007).

Selama fase generatif, cekaman suhu tinggi dalam periode singkat 
sekalipun dapat menggugurkan bakal bunga dan bunga yang mekar. Selama pengisian biji akan menginduksi senesense lebih awal, mengurangi pembentukan biji dan bobot biji, serta akan mengurangi hasil tanaman (Angio, 2016). Pengaruh lain dari cekaman suhu tinggi pada beberapa spesies tanaman adalah induksi sterilitas polen ketika tanaman terpapar suhu tinggi secara tibatiba pada fase sebelum atau selama pembungaan berlangsung (Muller and Rieu 2016). Kegagalan perkembangan polen dan antera oleh peningkatan suhu merupakan faktor penting yang berkontribusi terhadap penurunan jumlah bunga pada beberapa tanaman pada kondisi suhu tinggi.

Fase pembentukan malai pada tanaman padi sangat sensitif terhadap suhu tinggi (Weerakoon et al., 2008).
Selama tahap ini, stress akibat panas sangat memungkinkan untuk terjadinya strerilitas bunga, menurunnya kesuburan dan kehilangan hasil. Hal ini terutama disebabkan oleh menurunnya aktifitas serta perkecambahan polen, terbatasnya pertumbuhan tabung polen, rendahnya daya dehiscence polen, rendahnya polen yang mencapai kepala putik dan penyerbukan yang tidak sempurna (Matsui et al., 2001; Tan et al., 2006). Prasad et al., (2006) juga melaporkan bahwa suhu tinggi dapat mengakibatkan stres pada fase pembungaan sehingga menyebabkan penurunan produksi polen. Umumnya polen merupakan organ yang paling sensitif terhadap kondisi suhu tinggi (Wassman et al. 2009). Viabilitas serbuk sari pada suhu tinggi dapat dilihat pada Gambar 1.
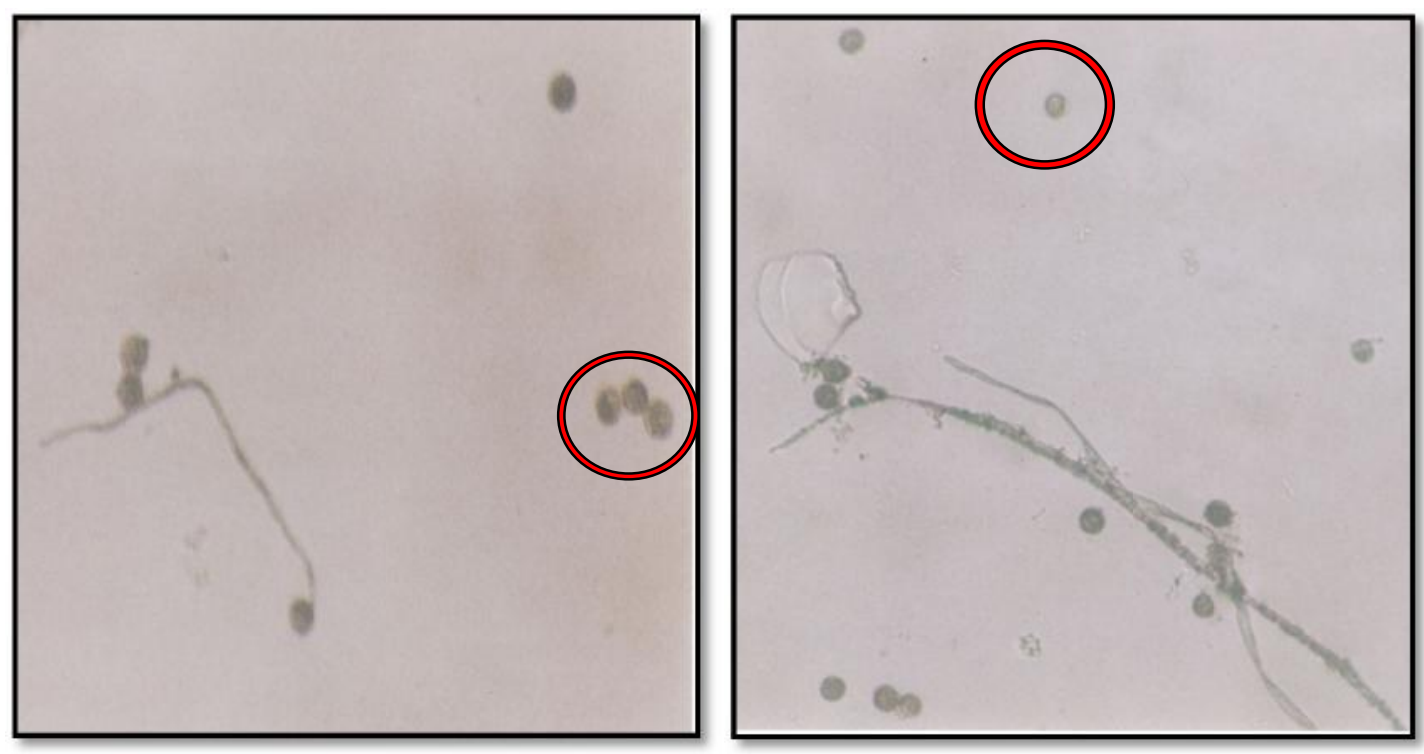

Gambar 1. Pollen tanaman padi yang banyak tidak berkecambah pada suhu $34{ }^{0} \mathrm{C}$, ditandai dengan tidak terbentuknya tabung polen (pollen tube), (lingkaran merah) (Ridha, 2011).

Zeng et al., (2008) mendapatkan bahwa varietas sensitif, dapat menghasilkan abnormalitas dari embrio sac pada temperatur tinggi. Keabnormalan embrio sac ini juga dapat mendorong terjadinya abnormalitas pada proses pembuahan. Berbagai penelitian menunjukkan bahwa temperatur harian 
yang melebihi $35{ }^{0} \mathrm{C}$ pada saat pembungaan menyebabkan sterilitas floret pada padi. Penyebab utama sterilitas yang disebabkan oleh temperatur tinggi adalah kegagalan penyerbukan yang disebabkan oleh rendahnya dehiscence antheca saat pembungaan (Matsui et al. 2000).

Peningkatan temperatur terutama pada saat pembungaan dapat meningkatkan sterilitas biji pada tanaman padi. Peningkatan sterilitas biji disebabkan oleh peningkatan sterilitas pollen dan pengurangan deposisi pollen yang viabel pada stigma (Tang et al., 2006). Berbagai penelitian menunjukkan bahwa temperatur harian yang melebihi
$35{ }^{0} \mathrm{C}$ pada saat pembungaan menyebabkan sterilitas floret pada padi. Penyebab utama sterilitas yang disebabkan oleh temperatur tinggi adalah kegagalan penyerbukan yang disebabkan oleh rendahnya dehiscence antheca pada saat pembungaan (Matsui et al., 2000). Selanjutnya Matsui et al., (1997) membuktikan bahwa pada varietas padi tertentu dengan temperatur $30{ }^{0} \mathrm{C}$ pada saat pembungaan dapat menyebabkan terjadinya sterilitas. Sterilitas tersebut dapat menyebabkan peningkatan gabah hampa sehingga mengurangi hasil seperti yang diharapkan.

Tabel 1. Effect of ambient (AT) and high temperature (ambient $+5{ }^{0} \mathrm{C}, \mathrm{HT}$ ) on pollen production, pollen reception (pollen shed), pollen viability and spikelet fertility of different rice cultivars during 2001 (Prasad et al., 2005)

\begin{tabular}{|c|c|c|c|c|c|c|c|c|c|}
\hline \multirow[t]{2}{*}{ Cultivar (C) } & \multicolumn{3}{|c|}{ Pollen production (number anther ${ }^{-1}$ ) } & \multicolumn{3}{|c|}{ Pollen reception (number stigma ${ }^{-1}$ ) } & \multicolumn{3}{|c|}{ Pollen viability (\%) } \\
\hline & AT & $\mathrm{HT}$ & $\begin{array}{l}\text { \% decrease } \\
\text { from AT }\end{array}$ & AT & HT & $\begin{array}{l}\text { \% decrease } \\
\text { from AT }\end{array}$ & AT & HT & $\begin{array}{l}\% \text { decrease } \\
\text { from AT }\end{array}$ \\
\hline L-204 & 945 & 211 & 77.7 & 14.3 & 4.0 & 72.1 & 91.6 & 68.7 & 25.0 \\
\hline M-202 & 1177 & 151 & 87.2 & 17.6 & 3.8 & 78.4 & 91.7 & 73.8 & 19.5 \\
\hline Labelle & 1496 & 591 & 60.5 & 17.1 & 6.0 & 64.9 & 76.8 & 60.2 & 21.6 \\
\hline Italica Livorna & 1174 & 306 & 73.9 & 21.7 & 8.8 & 59.4 & 96.2 & 71.8 & 25.4 \\
\hline S-102 & 1109 & 513 & 53.7 & 17.4 & 12.6 & 27.6 & 93.1 & 69.4 & 13.0 \\
\hline Koshihikari & 1322 & 430 & 67.5 & 18.1 & 10.8 & 40.3 & 79.7 & 62.2 & 22.0 \\
\hline M-103 & 965 & 499 & 48.3 & 17.4 & 10.4 & 40.2 & 98.8 & 79.6 & 19.4 \\
\hline $\mathrm{N}-22$ & 1380 & 1028 & 25.5 & 18.9 & 15.1 & 20.1 & 95.4 & 87.7 & 8.1 \\
\hline IR-8 & 1466 & 1234 & 15.8 & 17.2 & 15.3 & 11.1 & 93.6 & 89.6 & 4.3 \\
\hline IR-72 & 1311 & 1101 & 16.1 & 14.9 & 12.7 & 14.7 & 91.6 & 86.4 & 5.7 \\
\hline Mean & 1235 & 607 & & 17.5 & 10.0 & & 90.9 & 74.9 & \\
\hline $\operatorname{LSD}(0.05) \mathrm{T}$ & \multicolumn{2}{|c|}{84} & & \multicolumn{2}{|c|}{1.3} & & \multicolumn{2}{|c|}{4.3} & \\
\hline $\operatorname{LSD}(0.05) \mathrm{T} \times \mathrm{C}$ & \multicolumn{2}{|c|}{187} & & \multicolumn{2}{|c|}{2.8} & & \multicolumn{2}{|c|}{ NS } & \\
\hline
\end{tabular}

Data are the mean of 10 observations.

Hasil penelitian Prasad et al., tanggapan yang berbeda-beda terhadap (2005) perlakuan suhu, kultivar dan suhu tinggi di antara kultivar untuk interaksi antara suhu dan kultivar pada produksi polen. Penurunan produksi polen tanaman padi memberikan pengaruh yang karena suhu tinggi lebih besar pada signifikan terhadap produksi polen dan kultivar M-202 (87\%) diikuti oleh L-204 jumlah polen pada stigma (Tabel 1). Ratarata, suhu tinggi menurunkan produksi polen sebanyak $51 \%$ dan jumlah butir polen pada stigma sebesar $43 \%$. Terdapat (78\%), Italica Livorna (74\%), Labelle (61\%), S-102 (54\%) dan M-103 (49\%) sedangkan pengaruhnya lebih kecil pada kultivar N-22 (26\%). Demikian pula, 
jumlah polen pada permukaan stigma lebih rendah pada suhu tinggi dan pengaruhnya bervariasi di antara setiap kultivar. Pengaruh ini mirip dengan produksi polen dengan pengaruh negatif terbesar dari suhu tinggi pada kultivar M202 (78\%) diikuti oleh L-204 (72\%) dan Labelle (65\%), sedangkan pengaruh terkecil pada kultivar N-22 (20\%) dan S102 (27\%). Suhu tinggi menurunkan viabilitas polen dari 91 hingga $75 \%$, ketika dirata-ratakan pada semua kultivar.

Terdapat perbedaan yang sangat jelas akan sensitifitas terhadap temperatur tinggi diantara berbagai kultivar tanaman padi (Morita, 2008). Kultivar/varietas yang toleran terhadap temperatur tinggi menunjukkan anter dehiscence dan kesuburan floret yang lebih tinggi daripada varietas yang resisten pada keadaan temperatur tinggi (Matsui et al., 2001). Varietas yang sensitif terhadap temperatur tinggi dapat menghasilkan abnormalitas dari embrio sac. Keabnormalan embrio sac ini juga dapat mendorong terjadinya abnormalitas pada proses pembuahan (Zeng et al., 2008).

\section{DAMPAK CEKAMAN SUHU TINGGI TERHADAP AKUMULASI CADANGAN MAKANAN DALAM BIJI}

Temperatur secara langsung juga berperan terhadap perkembangan biji seperti pengisian biji dan laju produksi bahan kering pada biji (Kobata and Uemuki, 2004). Temperatur tinggi dapat menghambat perkembangan biji pada padi (Zakaria et al., 2002). Menurut Peng et al., (2004) setiap kenaikan suhu minimum sebesar $\quad 1{ }^{0} \mathrm{C}$ akan menurunkan hasil tanaman padi sebesar 10\%. Hasil penelitian Asseng et al., (2010) pada tanaman gandum di lapangan dengan suhu tinggi mencapai $40{ }^{0} \mathrm{C}$ selama 12 hari sebelum dan sesudah antesis mengakibatkan penurunan hasil biji per $\mathrm{m}^{2}$ sebesar $50 \%$.

Suhu tinggi pada tahap pemasakan menyebabkan penurunan berat biji, mengurangi pengisian biji dan peningkatan jumlah biji yang tidak sempurna, beras inti putih, beras putih susu yang mempengaruhi kualitas dan hasil panen beras (Yoshida et al., 1981; Tashiro and Wardlaw, 1989). Tanaka et al, (1995) melaporkan bahwa menurunnya hasil ketika suhu pada tahap pemasakan terlalu tinggi karena pemakaian energi yang berlebihan disertai dengan respirasi biji.

Selama pengisian biji, perubahan suhu dapat mengubah bahan kimia pada beras seperti pati, penyimpanan protein dan kandungan asam lemak, sehingga mempengaruhi kualitas gabah (Nagato and Chaudhry, 1969; Asaoka et al., 1985). Temperatur tinggi dapat mengurangi kandungan dan mengubah struktur butir pati serta berkurangnya kandungan amilosa (Counce et al., 2005). Perubahan struktur pati dikaitkan dengan pengaturan ekspresi enzim dan gen yang terkait (Jiang et al., 2003; Yamakawa et al., 2007). Protein menyumbang 6-10\% dari bahan kering butiran beras dan penting untuk kualitas biji (Hamaker, 1994). Selain itu, kandungan atau sifat kimia dari protein, dapat mempengaruhi karakteristik fisikokimia tepung beras (Martin and Fitzgerald, 2002). 

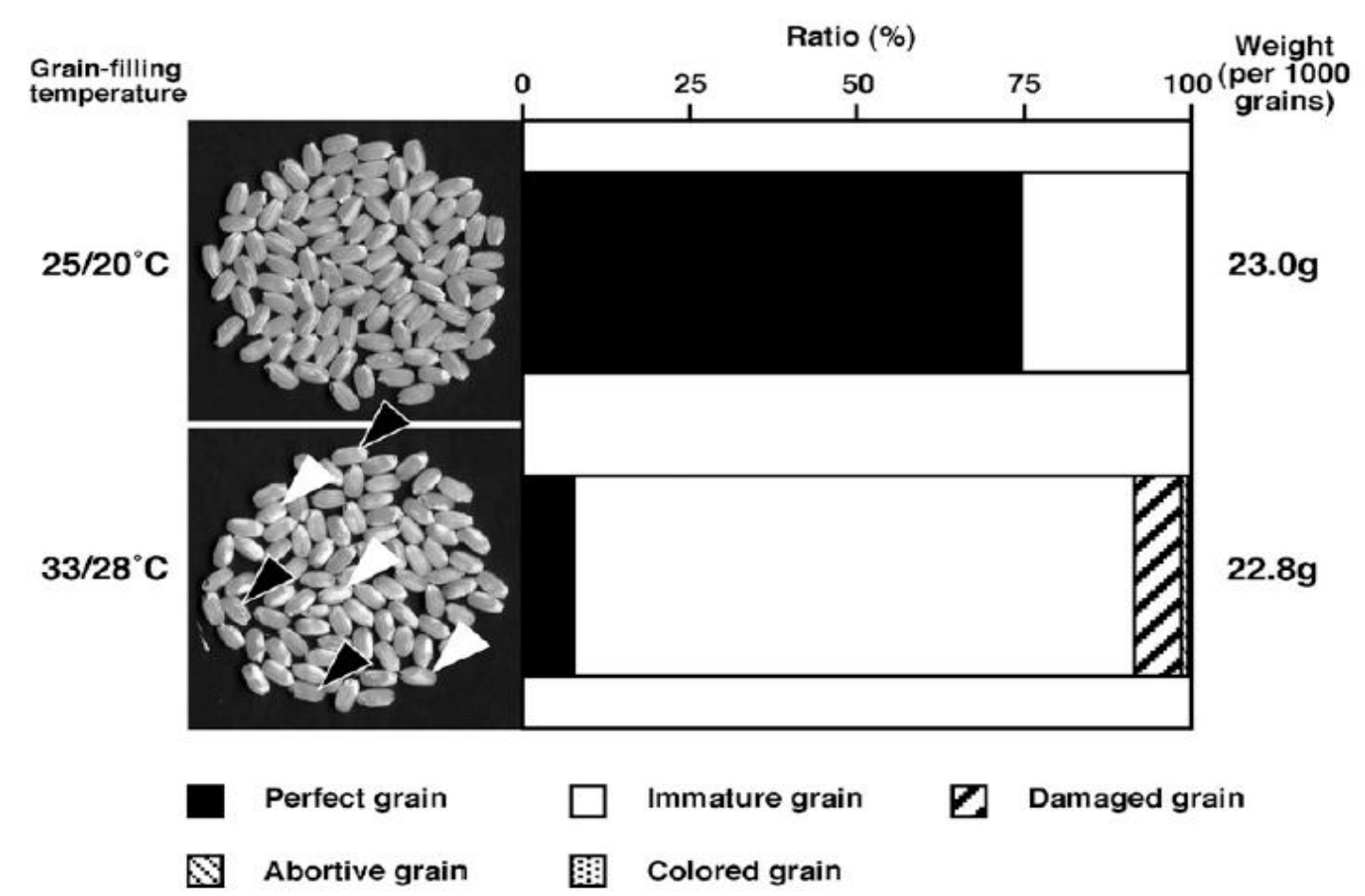

Gambar 2. Penampilan, rasio dan berat butiran gabah pada perlakuan suhu tinggi selama tahap pengisian gabah. Panah hitam dan putih menunjukkan biji-biji matang transparan dan sangat berkapur di bawah suhu $33{ }^{\circ} \mathrm{C} / 28{ }^{0} \mathrm{C}$ (Yamakawa et al., 2007).

Suhu tinggi selama periode Berdasarkan studi histologi, pengisian biji menyebabkan penurunan perkembangan endosperma pada bulir yang signifikan terhadap ukuran biji dan padi menunjukkan adanya transpor kandungan amilosa (Yamakawa dan asimilat dan air ke dalam kariopsis selama Hakata, 2010; Yamakawa et al., 2007). stadia matang susu. Pati dalam Stres suhu tinggi selama tahap pemasakan endosperma biji padi berubah secara memicu pengisian yang tidak seragam dan perlahaan dari fase cair menjadi padat gangguan dalam biosintesis penyimpanan, seiring dengan penurunan kadar air dan yang menyebabkan pembentukan kapur akumulasi transport asimilat selama (Sreenivasulu et al., 2015). Akibatnya, biji berkapur dengan mudah retak selama proses pemrosesan biji, yang menurunkan persentase beras kepala sebagai akibat dari peningkatan jumlah biji yang patah (Sreenivasulu et al., 2015). Pada kondisi tercekam suhu tinggi metabolisme gula dan transport prolin terhambat selama perkembangan bunga berlangsung (Sato et al. 2006).

Transport asimilat berhubungan dengan pergerakan air pada bulir padi. perkembangan biji. Perubahan ini memacu pemadatan endosperma dan pembentukan biji transparan (sempurna) (Horigane et al., 2001). Suhu tinggi meningkatkan perkembangan sel endosperm ketika biji mencapai fase akumulasi pati. Sehingga disimpulkan bahwa penurunan kadar air bebas yang lebih cepat dalam biji pada suhu tinggi menyebabkan terbentuknya biji putih punggung atau biji berkapur selama proses pematangan (Funaba et al., 2006). 
Pada kultivar peka, suhu $30{ }^{0} \mathrm{C}$ (Gambar 3). Terhambatnya pembentukan selama 14 hari setelah berbunga epidermis akan sangat mempengaruhi menyebabkan terjadinya penghambatan morfologi biji padi, terutama pati (Tanaka pembentukan lapisan epidermis et al., 2009).

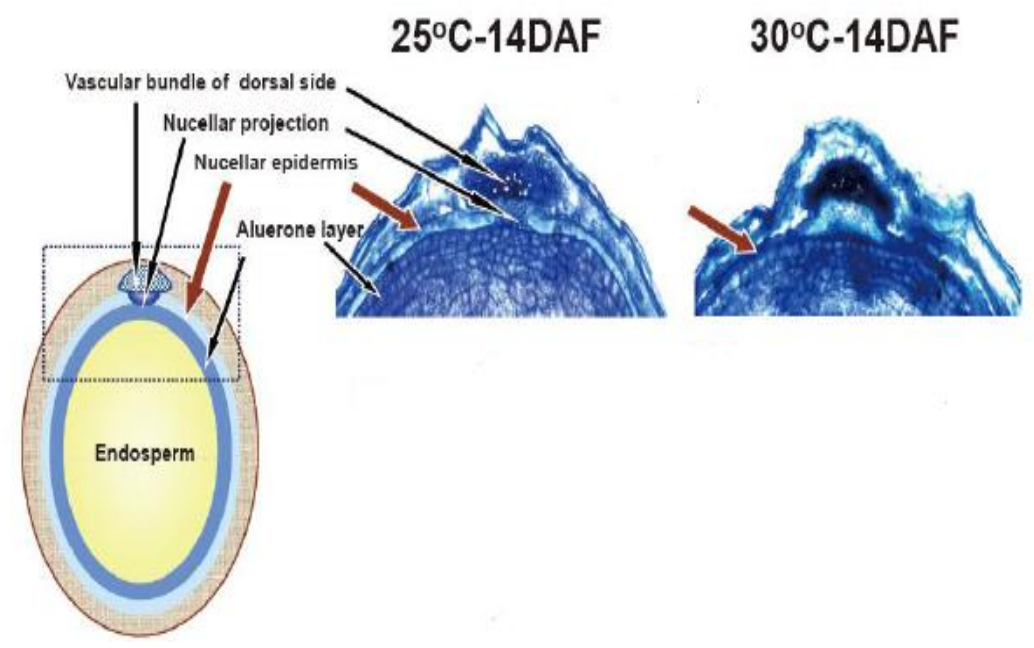

Gambar 3. Pengaruh suhu tinggi pada morfologi butir beras selama 14 hari setelah berbunga; Kiri, Ilustrasi penampang vertikal butir beras. Kanan, Sampel diwarnai dengan 0,1\% Toluidine Blue (Tanaka et al., 2009).

Scanning electron microscopy dari ruang udara yang besar, sedangkan biji bagian melintang biji padi matang transparan di bawah suhu normal memperlihatkan bahwa endosperm dari dipenuhi dengan butiran yang padat biji matang berkapur di bawah suhu tinggi (Gambar 4). mengandung butiran pati longgar dengan

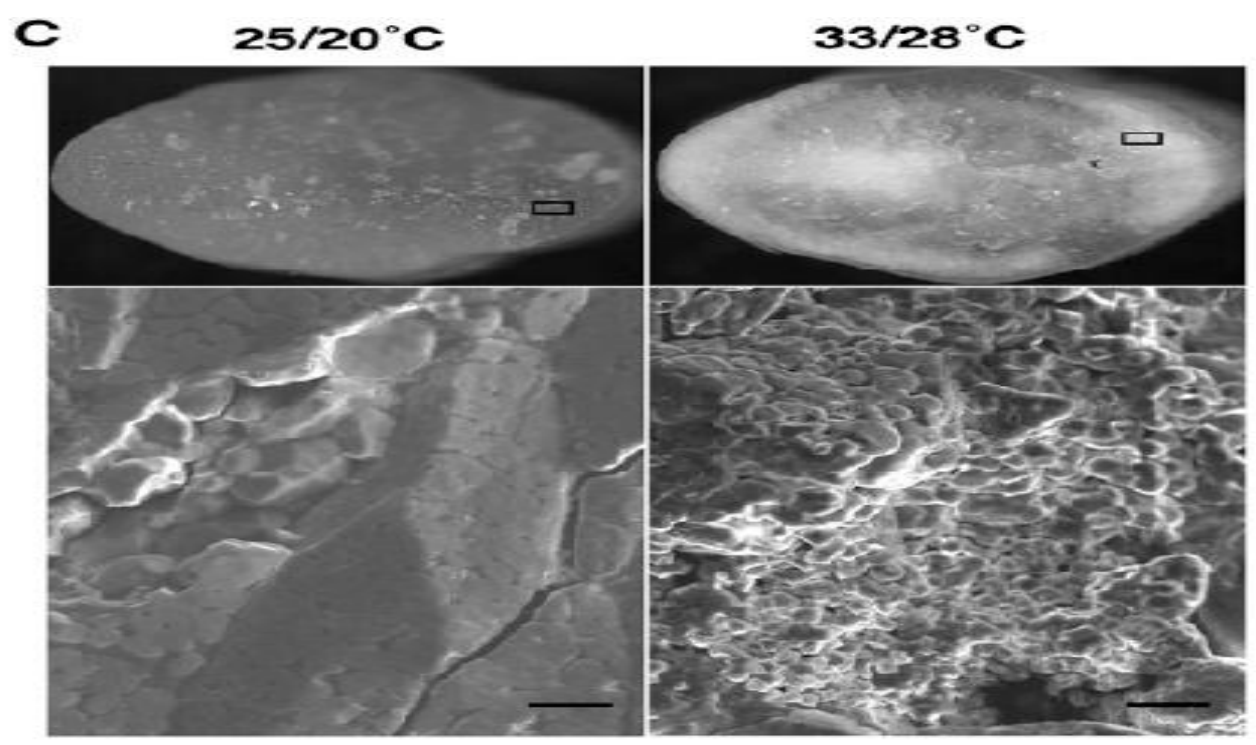

Gambar 4. Scanning elektron microscopy bagian melintang dari biji padi matang transparan $25{ }^{0} \mathrm{C} / 20{ }^{0} \mathrm{C}$ (kiri) dan matang berkapur $33{ }^{0} \mathrm{C} / 28{ }^{0} \mathrm{C}$ (kanan). Atas dan bawah, gambar mikroskop cahaya dan mikroskop scanning elektron (Yamakawa et al., 2007). 


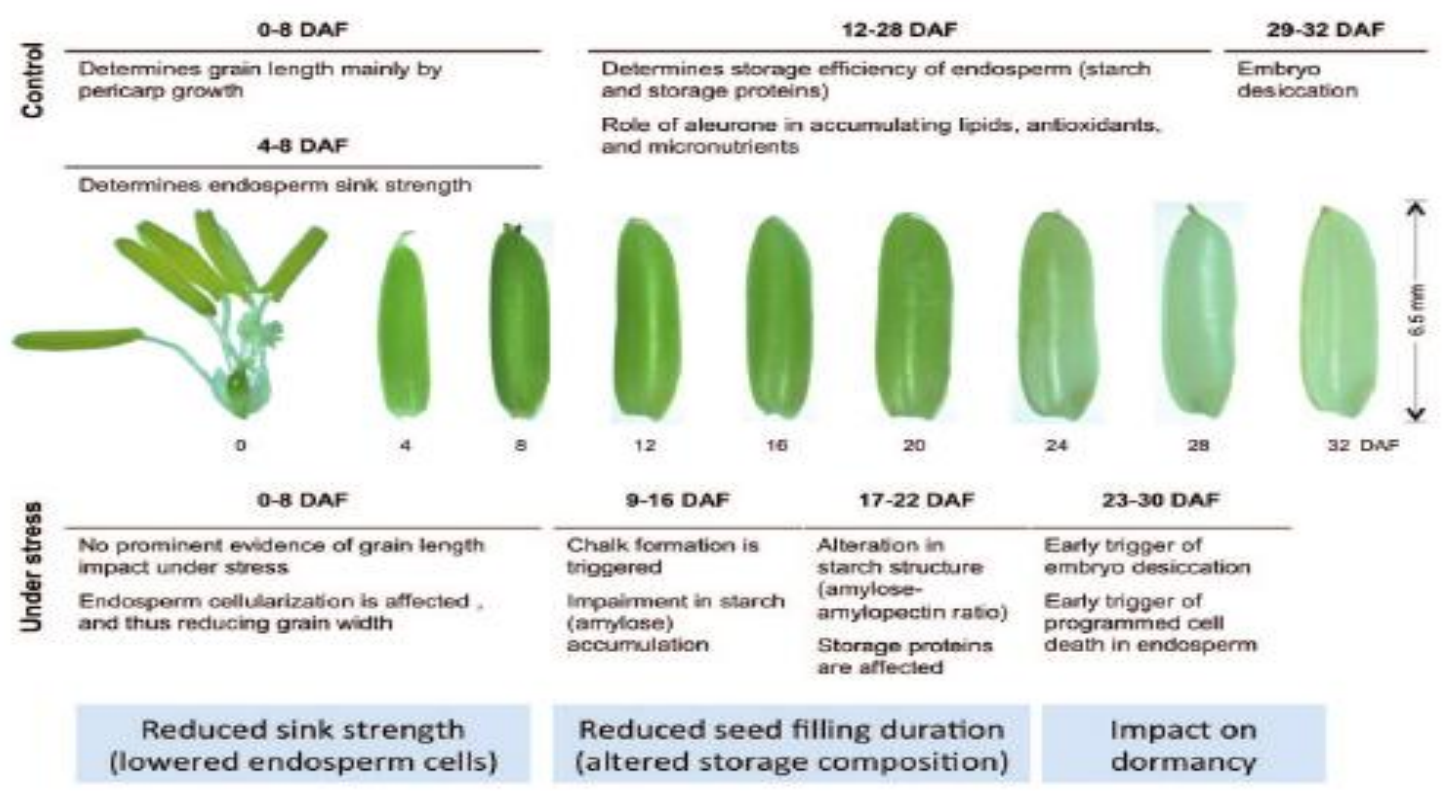

Gambar 5. Ontologi pengembangan biji. Gangguan yang disebabkan cekaman suhu tinggi selama perkembangan biji akan mempengaruhi kualitas biji padi; DAF : Hari setelah berbunga (Sreenivasulu et al., 2015).

Suhu tinggi meningkatkan fluiditas lipid membran tanaman, menurunkan kekuatan ikatan hidrogen, dan mengganggu interaksi elektrostatik antara kelompok polar protein dalam fase air membran (Taiz dan Zeiger, 2010). Oleh karena itu, suhu tinggi menyebabkan kebocoran ion, dan mengubah struktur dan komposisi membran tanaman. Suhu tinggi juga dapat merusak struktur tiga dimensi protein, yang menyebabkan hilangnya struktur dan aktivitas enzim (Taiz dan Zeiger, 2010). Gangguan dalam integritas membran dan stabilitas protein menghambat proses seluler. Cekaman abiotik pada suhu tinggi, memiliki pengaruh negatif pada berbagai sifat kualitas biji (Gambar 5).

Zakaria, (2005) menyatakan bahwa peningkatan temperatur selama kemasakan juga dapat menyebabkan penurunan kualitas biji terutama yang diakibatkan oleh terhambatnya akumulasi cadangan makanan pada biji. Munculnya "bagian putih buram" yang biasanya di dapatkan pada bagian gabah yang kurang sempurna pada musim panas diperkirakan mempunyai hubungan yang erat dengan sistem transfer dan transportasi cadangan makanan selama pembentukan biji. Bagian putih buram ini adalah bagian dari kerusakan yang disebabkan oleh temperatur tinggi selama kemasakan.

Kim et al. (2011) menyatakan bahwa cekaman suhu tinggi dapat mengakibatkan proses pengisian gabah berhenti lebih awal, berhentinya pengisian bukan karena kurangnya assimilat, tetapi lebih diakibatkan karena hilangnya aktivitas sink dan penuaan daun bendera secara cepat. Aktivitas sink yang tercekam suhu tinggi dapat menurunkan kemampuan translokasi dan sintesis enzim pati. Hal ini diperkuat oleh penelitian Mohammed dan Tarpley, (2010) yang melaporkan bahwa pengisian gabah pada padi dimulai pada bagian ujung malai, akibat dari cekaman suhu tinggi terjadi gangguan dalam transport assimilat pada 
bulir padi dan terjadi persaingan pengisian antar bulir pada malai.

\section{DAFTAR PUSTAKA}

Altuhaish, A. A. F. 2014. The improvement of wheat (Triticum aestivum L.) adaptability to tropical environment by putrescine application [Disertasi]. Institut Pertanian Bogor. Bogor (ID).

Angio, M. H. 2016. Respon Fisiologi dan Morfologi Tanaman Terung (Solanum melongena) Terhadap Cekaman Suhu Tinggi. Sekolah Pascasarjana Institut Pertanian Bogor. Bogor.

Asaoka, M., Okuno, K., Fuwa, H. 1985. Effect of environmental temperature at the milky stage on amylose content and fine structure of amylopectin of waxy and nonwaxy endosperm starches of rice (Oryza sativa L.). Agric. Biol. Chem. 49, 373-379.

Asseng, S., Foster, I. and Turner, N. C. 2010. The impact of temperature variability on wheat yields. Global Change Biology. Vol. 17, Issue 2, 997-1012.

Badan Meteorologi, Klimatologi dan Geofisika (BMKG). 2015. Publikasi Data Iklim Indonesia selama 40 tahun terakhir. Jakarta (ID).

Bhuyan, N., Basanta, N., Borah, K. and Sarma, R. N. 2007. Genetic diversity analysis in traditional lowland rice (Oryza sativa L.) of Assam using RAPD and ISSR markers Current Science. 93 (7): 967- 972.
Brewbaker, J. L. and Kwack, B. H. 1963.The essential role of calsium ion in pollen germination and pollen tube growth. American Journal of Botany 50: 859-865.

Chun, A., Song, J., Kim, K. J. and Lee, H. J. 2009. Quality of head and chalky rice and deterioration of eating quality by chalky rice. Journal of Crop Science and Biotechnology 12, 239-244.

Fischer, R. A., Maurer, R. 1978. Drought resistance in spring wheat cultivars. Aust. J Agric. 29:897912

Frey, F., Presterl, T., Lecoq, P., Orlik, A. and Stich, B. 2016. First steps to understand heat tolerance of temperate maize at adult stage: identification of QTL across multiple environments with connected segregating populations. J. Plant Breed. 129:945-961

Ghazi, N. and Al-Karaki. 2012. Phenological Development-Yield Relationships in Durum Wheat Cultivars under Late-Season HighTemperature Stress in a Semiarid Environment. ISRN Agronomy Vol. 2012, 7 pages.

Hamaker, B. R. 1994. The influence of rice protein on rice quality. In Rice Science and Technology; Marshall, W. E., Wadsworth, J. I., Eds. Dekker: New York, 1994; pp 177194.

Hanarida, I. S., Hasanah, M., Adisoemarto, S., Thohari, M., Nurhadi, A. dan Orbani, I. N. 2005. Seri Mengenal Plasma Nutfah Tanaman Pangan. Komisi Nasional Plasma Nutfah, Bogor. 
Haque, M. Z., Hasan, M. M., Rajib, M. M. R. and Hasan, M. M. 2009. Identification of cultivable heat tolerant wheat genotypes suitable for Patuakhali district in Bangladesh. J. Bangladesh Agril. Univ. 7(2): 241-246.

Hawker, J. S. and Jenner, D. F. 1993. High Temperature Affects the Activity of Enzymes in Committed Pathways of Starch Synthesis in Developing Wheat Endosperm. Aust. J. Plant Physiol. 20:197-209.

Inaba, K. and Sato, K. 1976. High Temperature Injury of Ripening in Rice Plant. VI. Enzymes Activities of Kernel as Influenced by High Temperature. Proc. Crop. Sci. Soc. Jpn. 45:162:176.

Intergovernmental Panel on Climate Change (IPCC). 2013. Climate Change 2013: Synthesis Report. Contribution of Working Groups to the Fourth Assessment Report of the Intergovernmental Panel of Climate Change. New York (USA): Cambridge Pr.

Jiang, H., Dian, W., Wu, P. 2003. Effect of high temperature on fine structure of amylopectin in rice endosperm by reducing the activity of the starch branching enzyme. Phytochemistry. 63, 53-59.

Kim J, Shon J, Lee CK, Yang W, Yoon W, Yang WH, Kim YG, Lee BW. 2011. Relationship between grain filling duration and leaf senescence of temperate rice under high temperature. Field Crops Res. 122: 207-213.
Kobata, T. and Uemuki, N. 2004. High Temperatures During The GrainFilling Period Do Not Reduce The Potential Grain Dry Matter Increase Of Rice. Agron. $J$. 96:406-414.

Martin, M., Fitzgerald, M. A. 2002. Proteins in rice grains influence cooking properties. J. Cereal Sci. 2002, 36, 285-294.

Matsui, T., Nomura, O. S., Ziska, L. H. and Horie, T. 1997. Effect of Hight Temperature and $\mathrm{CO}_{2}$ Concentration on Spikelet Sterility in Indica Rice. Field Crops Res. 51:213-219.

Matsui, T., Omasa, K. and Horie, T. 2000. High Temperatures at flowering inhibit swelling of pollen grains, a driving force for thecae dehiscence in rice (Oryza sativa L.). Plant Prod Sci 3:430-434

Matsui, T., Omasa, K. and Horie, T. 2001. The difference in sterility due to high temperature during the flowering period among japonicarice varieties. Plant Prod Sci 4:9093.

Mohammed, A. R., Tarpley, R. 2010. Effects of high night temperature and spikelet position on yieldrelated parameters of rice (Oryza sativa L.) plants. Europ J Agron. 33:117-123.

Morita, S. 2008. Prospect For Developing Measures to Prevent HighTemperature Damage to Rice Grain Ripening. Jpn. J. Crop. Sci. 77(1): 1-12.

Muller, F. and Rieu, I. 2016. Acclimation to high temperature during pollen 
development. Plant Reprod. 29: 107-118.

Nagato, K.; Chaudhry, F. M. A. 1969. Comparative study of ripening process and kernel development in japonica and indica rice. Proc. Crop Sci. Soc. Jpn. 38, 425-433.

Peng, S., Huang, J., Sheehy, J. E., Laza, R. C., Visperas, R. M., Zhong, X., Centeno, G. S., Kush, G. S. and Cassman, K. G. 2004. Rice yields decline with higer night temperature from global warming. Proceedings of The National Academy of Sciences. (USA). 101 : 9971-9975.

Prasad, P. V. V., Boote, K. J., Allen, L. H., Sheehy, J. E. and Thomas, J. M. G. 2005. Species, ecotype, and cultivar differences in spikelet fertility and harvest index of rice in response to high temperature stress. Field Crops Research 95: 398-411.

Ridha, R. 2011. Viabilitas Polen dan Performansi antar Kelompok Varietas Padi (Oryza sativa L.) Introduksi serta Hubungannya dengan Pembentukan Biji [Skripsi]. Fakultas Pertanian Universitas Syiah Kuala.

Shah, F., Huang, J., Cui, K., Nie, L., Shah, T., Chen, C. and Wang, K. 2011. Impact of high temperature stress on rice plant and its traits related to tolerance. Journal Of Agricultural Science. Hal 1-12. doi: 10.1017.

Sreenivasulu, N., Butardo, V. M., Misra, G., Cuevas, R. P., Anacleto, R. and Kishor, P. B. K., 2015. Designing climate-resilient rice with ideal grain quality suited for hightemperature stress. Jurnal of Experimental Botany. 66, 17371748.

Sultan, S. M. and Rao, L. V. S. 2013. Germplasm Collection From Last Remnants of Rice Landrace Genetic Diversity. int j conserv sci 4, 4, Oct-Dec 2013:467-476.

Tang, R. S., Zheng, J. C. and Zhang, D. D. 2006. The effects of high temperature on pollen vitality and seed setting of different rice varietas. Jiangsu J. Agric. Sci. 22:369-373.

Tanaka, K.R., Miyazaki, O.M., Ishibashi, Y., Yuasa, T. And Iwaya-Inoue, M. 2009. Changes in NMR relaxation of rice grains, kernel quality and physicochemical properties in response to a high temperature after flowering in heat-sensitive rice cultivars. Plant Prod. Sci. 12:185-192.

Tashiro, T. and Wardlaw, I.F. 1989. A comparison of the effect of high temperature on grain development in wheat and rice. Ann. Bot. 64 : 59-65.

Tschirley J. 2007. Climate Change adaptation : Planning and practices. Power Point Keynote Presentation of FAO Environment. Climate Change. Bioenergy Division. 10-12 September 2007. Rome.

Weerakoon, W. M. W., Maruyama, A. and Ohba, K. 2008. Impact of humidity on temperature induced grain sterility in rice (Oryza sativa L.). J. Agron. And Crop Sci. 194:135-140 
Yamakawa, H., Hirose, T., Kuroda, M. and Yamaguchi, T. 2007. Comprehensive Expression Profiling of Rice Grain FillingRelated Genes under High Temperature Using DNA Microarray. Plant Physiology. Vol. 144, pp. 258-277

Yamakawa, H., Hakata, M., 2010. Atlas of rice grain filling-related metabolism under high temperature: joint analysis of metabolome and transcriptome demonstrated inhibition of starch accumulation and induction of amino acid accumulation. Plant Cell Physiol. 51, 795-809.

Yoshida, S., Satake, T. and Mackill, D.S. 1981. Heat temperature stress in rice. IRRI research paper series.
IRRI, Manila, Philippines. $67: 1$ 15.

Zakaria, S. 2005. Effect of temperature in ripening stage on the appearance of nucellar epidermis and reserves accumulation in endosperm of rice (Oryza sativa L.). Jurnal Agrista.

Zeng, Y. X., Chao, Y. H., Yong, G. L., Jin-Ql. and Xiang, D. L. 2008. Abnormalities occurring during fermale gametophyte development result in the diversity of abnormal embryo sacs and leads to abnormal fertilization in indica/japonica hybrids in rice. J. Integr. Plant Biology. 50: 941-950. 